\title{
GEOPHYSICAL CHARACTERIZATION OF AQUIFERS IN THE SALITRE RIVER BASIN, BAHIA STATE, BRAZIL, USING RESISTIVITY SOUNDINGS AND ELECTRICAL TOMOGRAPHIES
}

\author{
Olivar Antônio Lima de Lima
}

\begin{abstract}
The Salitre River basin, which is located in the semi-arid land of northeastern Brazil, is annually faced with severe surface-water scarcity. Two main aquifer systems, which are distributed in depth, can be exploited to supply the water needs of the population and its present agro-industrial development: (i) a fractured-karst, water-table component, totally developed within the upper carbonate sequence of the Salitre Formation; and (ii) a fractured-clastic, semi-confined component, most likely associating lower Salitre limestones with the meta-sandstones of the Morro do Chapéu Formation. Geophysical efforts have been useful in developing a regional, three-dimensional characterization of these two aquifer components of the Salitre river aquifer system and in detailing a useful electric tomographic scheme to implement their exploration. The geophysical survey, which comprised 64 Schlumberger electrical soundings of resistivity and five tomographic sections, was combined with well data to define the geometric and hydraulic characteristics of these aquifer components. The inversion of the resistivity data, under the control of the well data, was useful to reduce electrical ambiguities and to better define the depth of the water table and that of the thick, impervious aquifer substrate. The lateral and depth boundaries of the fracture-karst aquifer zones were outlined, allowing the estimation of a total reserve of approximately 100 billion $\mathrm{m}^{3}$ of groundwater. Chemical analysis of water samples collected at production wells was used to define a water quality zoning within the basin. These results are very important to define an optimum exploration regime for the groundwater available in the basin.
\end{abstract}

Keywords: electrical sounding, tomographic section, Salitre aquifer system.

RESUMO. A bacia hidrográfica do rio Salitre faz parte da região semiárida da Bahia e, por isso, apresenta severa escassez de água superficial. Dois principais componentes aquíferos, distribuídos em profundidade, podem ser explorados para suprir as necessidades hídricas da população humana e de seu incipiente desenvolvimento agroindustrial: (i) um componente cárstico-fraturado, de natureza livre, desenvolvido nas rochas carbonáticas superiores da Formação Salitre; e (ii) um componente fraturado, semi-confinado, combinando rocha basais da sequência Salitre e unidades meta-quartzíticas da Formação Morro do Chapéu. Foram executadas 64 sondagens elétricas verticais usando o arranjo Schlumberger de eletrodos, centradas em pontos selecionados da bacia, e cinco seções tomográficas de resistividade, para detalhar a estrutura subsuperficial de locais selecionados. A inversão dos dados de resistividade aparente, com controle de informações de poços, foi útil para reduzir ambiguidades elétricas e melhor definir as profundidades do nível estático e do topo do espesso substrato impermeável do sistema aquífero Salitre. Esses estudos permitiram avaliar, regionalmente, os recursos hídricos subterrâneos da bacia, em termos de geometria e características hidráulicas, bem como propor um procedimento para efetuar tomografia elétrica bidimensional, visando sua efetiva exploração por meio de poços. Os limites laterais e em profundidade das zonas de maior carstificação e de densos fraturamentos foram delineados, possibilitando estimar uma reserva total de água no sistema do rio Salitre em cerca de 220 bilhões de $\mathrm{m}^{3}$. Análises físico-químicas de amostras de água coletadas em poços foram usadas para caracterizar a variabilidade na qualidade da água subterrânea na bacia. Tais resultados podem ser usados para planejar um regime de exploração eficiente e conservativo das reservas de água subterrânea disponíveis.

Palavras-chave: sondagem elétrica, seção tomográfica, sistema aquífero Salitre. 


\section{INTRODUCTION}

The Salitre River basin in the north-central sector of the Bahia state is a small sub-basin on the right margin of the São Francisco river, and it covers a surface extent of approximately $14,500 \mathrm{~km}^{2}$ (Fig. 1). Its intermittent water-surface streams dominantly drain the meta-sedimentary terrain of the geologic and geomorphic domain referred to as the Chapada Diamantina. Because of some litho-structural constraints, three major aquifer units are recognized in this area: (i) a pure fractured system, which is located at the north end of the basin and installed on the high-grade metamorphic rocks that compose the substrate of the São Francisco craton; (ii) a fractured-clastic system, which is primarily associated with the highly silicified meta-sandstones of Morro do Chapéu Formation; and (iii) a fractured-karst system, which is developed within the carbonate rocks of the Salitre Formation.

Because of the severe semi-arid climate, surface-water availability is scarce in most of the area. In the low Salitre course, there is some available reserve associated with the upper-level dams constructed in the São Francisco River. On the high Salitre watershed, the availability is improved by the higher and betterdistributed rainfall in the Chapada Diamantina. However, the large area of the medium Salitre is the most water-deficient of the three. Therefore there are serious problems of water supply, both to meet the basic needs of the distributed population and to satisfy its agro-industrial development, which is centered on the exploration of the "Beige-Bahia" marble and of limestone for cement manufacturing as well as and chrome ore and precious stones (emeralds) near Campo Formoso (CBPM, 2004).

The unique, permanent water sources that can be used to meet the regional demands are the karst-fissure and clastic-fissure aquifers that almost equally cover the area of the basin (Fig. 1). The Morro do Chapéu Formation hosts clastic-fissure aquifer zones with a semi-confined behavior. Wells drilled in these zones have a mean yield of $7.2 \mathrm{~m}^{3} / \mathrm{h}$. In the carbonate rocks of the Salitre Formation, fractured-karst aquifers are developed, where the storage and water flow occur through wide cracks and large channels and caves generated by groundwater dissolution. Their wells have an average discharge of $6.5 \mathrm{~m}^{3} / \mathrm{h}$. However, the geometric and dimensional characteristics of these aquifers and the groundwater flow patterns and hydraulic interactions between them have not yet been evaluated, even on a regional scale (CEl, 1986; Brito, 2003; Lima, 2003).

There is a strong limitation on the extent of the exploration of these dominantly fracture-controlled reservoirs that can be performed without a detailed geological analysis. The high rate of dry wells (on the order of $30 \%$ ) and the high water salinity of the karst-fissure wells are among the main hydrogeological problems in the exploration of these aquifers. Despite these difficulties, there is a huge amount of stored water in this aquifer system that must be properly located and explored. Estimates based on regional water balance suggest an annual water availability of $3.6 \times 10^{8} \mathrm{~m}^{3}$ (CEl, 1986). The challenge is to develop efficient technologies for locating, measuring and extracting the available reserves with acceptable quality and economic value.

This work summarizes the results of geological and geophysical studies performed to regionally define the main geometricstructural, hydraulic and chemical features of the karst-fissure aquifers, that cover a large portion of the Salitre River basin. To a lesser extent, some characteristics of the clastic-fissure aquifer system were also evaluated. In addition to a geologic and geomorphic analysis based on satellite images and field observations and an extensive geophysical survey, more than 30 results from production wells drilled both in carbonate rocks and in metasandstones aquifers, were considered in this analysis.

Sixty-four vertical electrical soundings (VES) were performed and expanded to explore the subsurface - reaching aquifers up to a depth of approximately $200 \mathrm{~m}$. Five electric tomographic transverses, using distributed depth soundings, were surveyed to investigate some selected locations in geater detail. Data from physical-chemical analyses of water samples collected at wells that penetrate both aquifers in the area were also considered. The geological and geophysical results were used to evaluate the available water reserves, the natural changes in water quality, and the mixtures and improvement that may occur during the exploitation of the combined aquifer units.

\section{REGIONAL FEATURES}

The Salitre River basin has an almost ellipsoidal shape, which is north-south elongated, and the main water course, the Vereda da Tábua or Salitre River, runs through its axial zone. The topographic characteristics within the basin can be grouped into three main units: (i) The first is a marginal zone of mountains and plateaus with elevations ranging from 1000 to $1400 \mathrm{~m}$, which is modeled over the meta-sandstones of the Morro do Chapéu Formation and densely drained by rivers and creeks in a subrectangular structurally controlled drainage pattern; (ii) The second is a wide central floodplain, with a main elevation of approximately $520 \mathrm{~m}$, composed of the carbonate rocks of the Salitre Formation. Within this plain-graded area, which has low runoff and vegetation-density values, residual levels and karst features, such as sinkholes and caves, are preserved. Major rivers in this central portion have carved out their valleys; (iii) Finally, the 


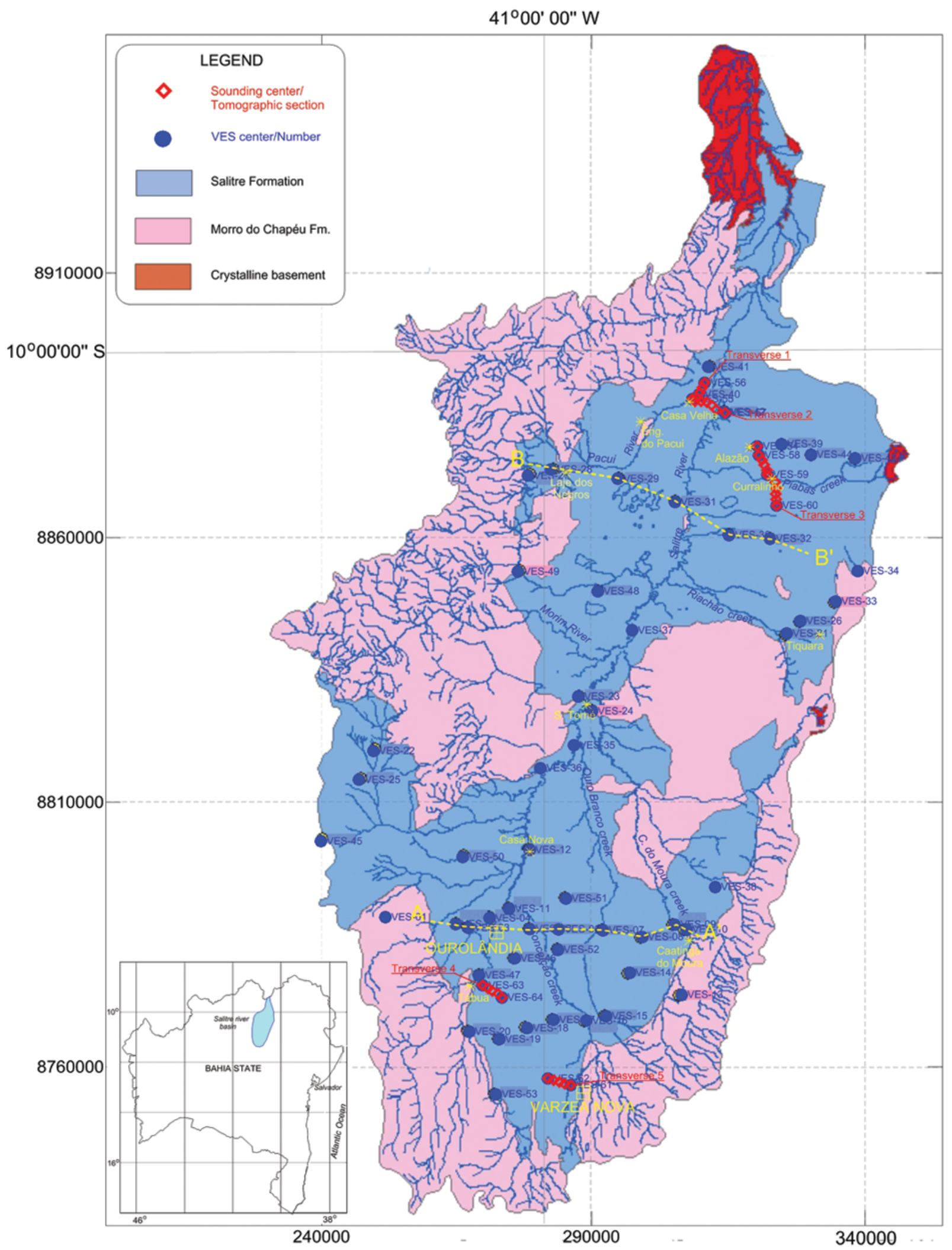

Figure 1 - Geologic map of Salitre river basin showing the location of VES centers and tomographic transverses. 
third is a transition zone, with ascending elevations between 550 and $650 \mathrm{~m}$, which reflects the small lithologic variability in the Salitre Formation and also the unconformity between the two meta-sedimentary sequences.

The sources of the Salitre River are located on the slopes of the Chapada Diamantina, in an area called Boca da Madeira (Morro do Chapéu county), and its mouth empties into the São Francisco River (Fig. 1). Its main tributaries are as follows: (i) on the left margin, the rivers Marim, Preto and Laje or Pacuí and the creeks Vereda do Covão, Olhos D'Agua, Lagoa Bonita, Salobro, Escurial and Parafuso; and (ii) on the right margin, the rivers Preto and Caatinga do Moura and the creeks Conceição, Barris, Santo Antonio, Ouro Branco, Varzinha and Piabas. These currents are controlled by conjugated linear structures, that are mainly oriented along the NNE-SSW direction, but some structures lie nearly east-west or north-south.

The primary vegetation in the region is of the savanna and "caatinga" types, characterized by small trees that are isolated or sparsely grouped on a nearly continuous carpet of grasses and woody shrubs. In large areas of the mountains and plateaus, the natural vegetation is being replaced by extensive coffee plantations and other irrigated crops.

Climate types in the basin include the semi-arid tropical climate in the central zone, which has an annual total rainfall below $500 \mathrm{~mm} /$ year and an average annual temperature of $29.4^{\circ} \mathrm{C}$, and the sub-humid tropical climate in the mountainous borders, which have an annual rainfall below $900 \mathrm{~mm} / \mathrm{year}$ and an average annual temperature of $26.4^{\circ} \mathrm{C}$. The rainfall concentration period extends from March to December, and there is a second period from November to April (CEl, 1986)

\section{GEOLOGICAL FRAMEWORK}

The geologic units underlying the Salitre River basin are represented by rocky domains formed from the Archean to Neoproterozoic ages (Fig. 1). The oldest domain, which contains graniticgneisses and greenstone rocks, is located near the northern end of the basin and constitutes the basement of the São Francisco craton. Superimposed on this oldest core, with an erosional unconformity, are the Mesoproterozoic continental sediments of the Chapada Diamantina Group and the Morro do Chapéu Formation, which are dominated by sandstones of high maturities interlayered with conglomerates, mudstones and limestones. This sedimentary sequence has undergone tectonic deformation and low-grade metamorphism during the Proterozoic. After a remarkable time lapse, marked by a wide erosional unconformity glacialmarine sediments of the late Precambrian ages were deposited, consisting of (i) sandstones, siltstones, argillites and conglomerates with faceted pebbles and boulders, characteristic of the Bebedouro Formation and (ii) pelitic and carbonate rocks of the Salitre Formation, deposited in a broad epicontinental shallow sea (Guimarães et al., 2012). The metamorphism of this upper unit is very incipient and its tectonic style is dominated by brittle failure.

\section{Litho-stratigraphic Features}

The Archean-Paleoproterozoic crystalline basement is composed of medium to high-grade metamorphic rocks (gneisses, granulites and migmatites), which have been intruded by granitic plutons and are associated with greenstone bodies of magmatic and volcano-sedimentary origin. This old terrain is overlaid with terrigenous sediments of an extensive Mesoproterozoic coverage of the Chapada Diamantina Group and the Morro do Chapéu Formation. Within the Salitre basin, however, only the meta-sandstones of the Morro do Chapéu Formation are outcropping and have hydrogeological importance.

The Morro do Chapéu Formation comprises a thick tabular package of sandstones with cross-stratified layers of medium to large size, interlayered with plane-parallel sandstones of varying grain size, siltstones, laminated mudstones and discontinuous lenses of conglomerates. This succession was deposited in an estuarine environment through the interaction of river currents, tides and winds.

The Precambrian litho-stratigraphy filling the synform ends with the deposition of the Neoproterozoic glacial-marine sediments of the Bebedouro and Salitre formations, which unconformably overlie the rocks of the Morro do Chapéu Formation. The Bebedouro Formation consists of mudstones with conglomerate lenses, siltstones and arcosean sandstones. These occur as narrow and discontinuous lenses at the base of the limestones and have no hydrogeological importance. In contrast, the Salitre Formation is dominantly composed of detrital carbonates (gray limestones with microcrystalline dolomites), which contain interbedded terrigenous rocks (mudstones) and occupy more than half of the watershed area.

The Salitre sequence shows a complex distribution of depositional facies, which include: (i) fine to coarse dark-gray calcarenites, calcisiltites and calcilutites deposited by the action of waves and currents; (ii) calcisiltites, lime mudstones and thin gray-colored calcarenites deposited in coastal areas by the action of tidal waves; (iii) dark-gray lime mudstones deposited in protected areas, such as lagoons and tidal plains; and (iv) calcilutites and fine to medium calcarenites, dark-gray to black in color, deposited in a platform environment (Guimarães et al., 2012). This 
compositional complexity has a strong influence on the deformation behavior of these rocks especially in their brittle behavior and the density distribution of fractures within faulted zones.

\section{Tectonic Features}

The rocks of the Chapada Diamantina Group and of the Morro do Chapéu Formation were subjected to a regional metamorphism of greenschist facies and to concentric tectonic folding which generated large antiforms and synforms of nearly NNE axial orientation plunging to the north. The marine carbonate deposits are preserved in large synforms as in the Salitre basin. They are also marked by gravity sliding folds with an axial plane that is oriented nearly east-west and dips to the north.

In addition to folding, the Precambrian sequences were crossed by conjugate systems of large normal, reverse and strikeslip faults, in response to the Brazilian orogenesis acting on the border of the São Francisco craton. This brittle tectonics appears to have been reactivated many times, with particular emphasis during the processes of east-west crustal stretching and compression associated with the rupture of the continent Pangaea. The folding axis and the fault traces control the main drainage courses of the Chapada Diamantina.

The general directional trends of the conjugated fractures, which are usually perpendicular to the lithological layering, are ENE and WSW, with transverse cracks oriented nearly east-west and north-south. In many limestone outcrops, dense fracture sets parallel to the lithologic layering are also observed.

Due to the low metamorphism and intense silicification, the porosities and permeabilities of these primary rocks have been strongly modified. Presently their hydraulic properties at various scales of analysis are primarily controlled by faults, fracture systems and dissolution channels.

A consequence of this pervasive brittle tectonics is the multiple occurrence of karst features, such as wide conduits and caves of kilometric extent 10 to $20 \mathrm{~m}$ in height and width. Among these are the two largest Brazilian caves, the Toca da Boa Vista (with $105 \mathrm{~km}$ of mapped conduits) and the Toca da Barriguda (with $30 \mathrm{~km}$ of mapped conduits), which are located east of the Laje dos Negros village in Campo Formoso county (Auler \& Smart, 2002; Wikipedia, 2009). Also, worth noting are the Sumidouro bridges, the Convent and the Tiquara caves, which are also Iocated in Campo Formoso, and the Poço Verde cave near the city of Ourolândia. These karst features, which were developed by the dissolution of the carbonates by acidified groundwater, portray the complex fracture geometry of the Salitre Formation and are excellent geologic vestiges of a rich underground paleo-drainage.
Maps of the labyrinthine caves Toca da Boa Vista and Toca da Barriguda show that they follow conjugated fractures within wide belts of dense fracturing oriented SW-NE, and they are approximately $800 \mathrm{~m}$ in width and have longitudinal extents of 3.9 and $1.9 \mathrm{~km}$, respectively. The orientations of their main internal caves coincide with the master conjugated fracture sets, attesting to the link between the caves and the fractures. These areas of concentrated fractures are usually associated with major faults sectioning the entire meta-sedimentary package.

Finally, it should be noted the occurrence of geologic units comprising the Tertiary-Quaternary roof sequences represented by the detrital-lateritic rocks of the Pleistocene Caatinga Formation, and the Quaternary alluvial deposits that also have no hydrogeologic importance.

\section{GEOPHYSICAL SURVEYS}

The electrical resistivity of a rock is primarily determined by the quantity and salinity of its saturating water, the amount and connectivity of its void-space and the proportion of metallic and/or other mineral species with a surface electrical conductivity that are dispersed in its solid matrix. The electrical resistivity method has found wide success in hydrogeology, because of its good definition of the structural aquifer geometry and its water quality and because it allows the determination of the amount of clays and the spatial variability of their hydraulic properties (Ward, 1990; Lima \& Sri Niwas, 2000).

Sixty-four VES were performed using the Schlumberger electrode array expanded to a maximum current-electrode spacings $A B / 2$, of $1000 \mathrm{~m}$. The sounding centers were selected along major and minor roads to cover, in a more or less uniform fashion, the full extent of the area occupied by carbonate rocks. A few sounding were specially performed to characterize the behavior of the fractured-clastic Morro do Chapéu aquifer unit.

The data were measured with a SYSCAL R-2 and a SYSCALPRO electrical units, which were manufactured by IRIS Instruments Inc. and are owened by the CPGG/UFBA. These systems have $250 \mathrm{~W}$ of electrical power and are fed by $12 \mathrm{~V}$ batteries coupled to DC-DC converters capable of producing a maximum output voltage of $800 \mathrm{~V}$. Copper stakes buried $60 \mathrm{~cm}$ in the ground were used as current and potential electrodes.

The electrical sounding technique was chosen based on the observation that the general structure of the area is represented by a two relatively uniform lithologic sequences, which are sectioned by large geologic faults and associated with wide belts of dense conjugated fracturing. In addition, the karst processes acting on the carbonates produces vertical variation in resistivity in 
both the fractured zones and their lateral borders. Therefore, we adopted the hypothesis that within the extent of a single electrical sounding the resistivity variations would be, in general, dominantly vertical.

Additionally, to test an appropriate scheme for well locations in the Salitre River aquifer system, five electric-tomographic sections were acquired using multiple Schlumberger VES spaced $1000 \mathrm{~m}$ to $1500 \mathrm{~m}$ apart, along transverses crossing suspected fractured zones. The constructed two-dimensional resistivity sections were quantitatively interpreted with two-dimensional automatic inversions using the RES2DINV package from Geotomo Software.

Figure 2 shows a map of the variation in the observed apparent resistivity $\left(\rho_{a}\right)$ measured for an $\mathrm{AB} / 2$ electrode spacing of $100 \mathrm{~m}$. For this spacing the figure mainly reflects the resistivity changes located within the main karst-fissure aquifer. The apparent-resistivity values are generally low (between 10 and $45 \Omega$.m), indicating a high-porosity underground reservoir saturated with slightly saline water. The apparent resistivity increases in a regular manner from the center to the edges of the basin, indicating a reduction in the karst process along the same direction. Furthermore, the existence of closed contours suggests the presence of resistivity contrasts, possibly because of folding or regional faults. Thus, it appears that even from the crude $\rho_{a}$ function, we may extract qualitative information on lithologic variations, water content or the presence of large deformation structures.

\section{Electrical Sounding Data}

To reduce the electric equivalence effects between different onedimensional models, the VES data were inverted by adopting the following sequential process: (i) Initially, the data were automatically inverted using the procedure proposed by Zohdy (1989), in which the inversion is carried out using models in which the number of layers is equal to the number of sampling points in the sounding. For this procedure, the free program RES1D, from Geotomo Software was used; (ii) The model obtained in the first step was analyzed by grouping layers of identical or similar resistivities to build an initial model with fewer layers, which was subjected to a non-linear least-squares inversion (Vozoff, 1958; Koefoed, 1979). At this stage, the program RESIST1.0, which was written by Vander Velpen \& Sporry (1993), was used.

First, the electrical soundings that were centered close to water production wells were adjusted by fixing some of the available parameters, such as the depth to the water table and/or to some distinct lithologic interface, to further reduce the ambiguity of the geoelectrical interpretation. By associating the VES results with well data, the additional curves were inverted using one-dimensional resistivity models and the described fitting procedures.

The adopted inversion scheme and the use of "a priori" information in the inversion process are illustrated in Figures 3 and 4. The observed data of VES-12 and VES-26 were fitted, with an average least-squares error smaller than $2 \%$, starting from a model based on the initial analysis of the automatic inversion by fixing the depth or thickness of specific layers in accordance with the well data and adjusting the apparent-resistivity values to the preset error limit. The VES-12 and VES-26 curves also highlight that the karst development is greater at the center compared to the edges of the basin. Well CERB2-1869, which has a depth of $46 \mathrm{~m}$ has a production rate of $34 \mathrm{~m}^{3} / \mathrm{h}$ and a drawdown of only a few centimeters, while well CERB1-6729, which has a depth of $120 \mathrm{~m}$ has a production rate of $17 \mathrm{~m}^{3} / \mathrm{h}$ and a drawdown of tenths of meters.

The observed $\rho_{a}$ curves have "valley"-shaped initial branches and ascending terminal branches, ending with angles close to or greater than $45^{\circ}$. Based on their shapes, the curves were grouped into three classes: (i) initial U-shaped asymmetric branches of flat or slightly inclined bases and ascending normal or sigmoid terminal branch (39\% of total); (ii) initial V-shaped branches and ascending terminal normal or sigmoid terminal branches (24\% of total); and (iii) curves that do not belong to class 1 or 2, combining features of "hills" and "valleys", usually with ascending terminal branches ( $37 \%$ of total). Normally, the "valleys" correspond to fracture or karst aquifer intervals, the intermediate resistive levels represent only fractured aquifer regions and the straight terminals branches indicate local, infinitely resistive substrates. Figures 5, 6 and 7 contain VES curves that are representative of these three sets.

Figure 5 shows some typical examples of sounding curves of the first class. Their interpreted results reveal the existence of an upper, thick and well-developed karst aquifer with a distinct water-table definition (phreatic aquifer). This first horizon, in many places, overlaps an intermediate geoelectrical interval of a few hundred $\Omega$.m in resistivity. By associating VES and well data and on the basis of the electrical resistivity values, these levels were interpreted as consisting of densely fractured limestone with little or no dissolution. The high-resistivity substrate may be hard limestone or hydraulically closed meta-sandstone.

The second pattern (type 2 curves, Fig. 6 ) is also recognized as the superposition of two aquifer intervals, which are sepa- 


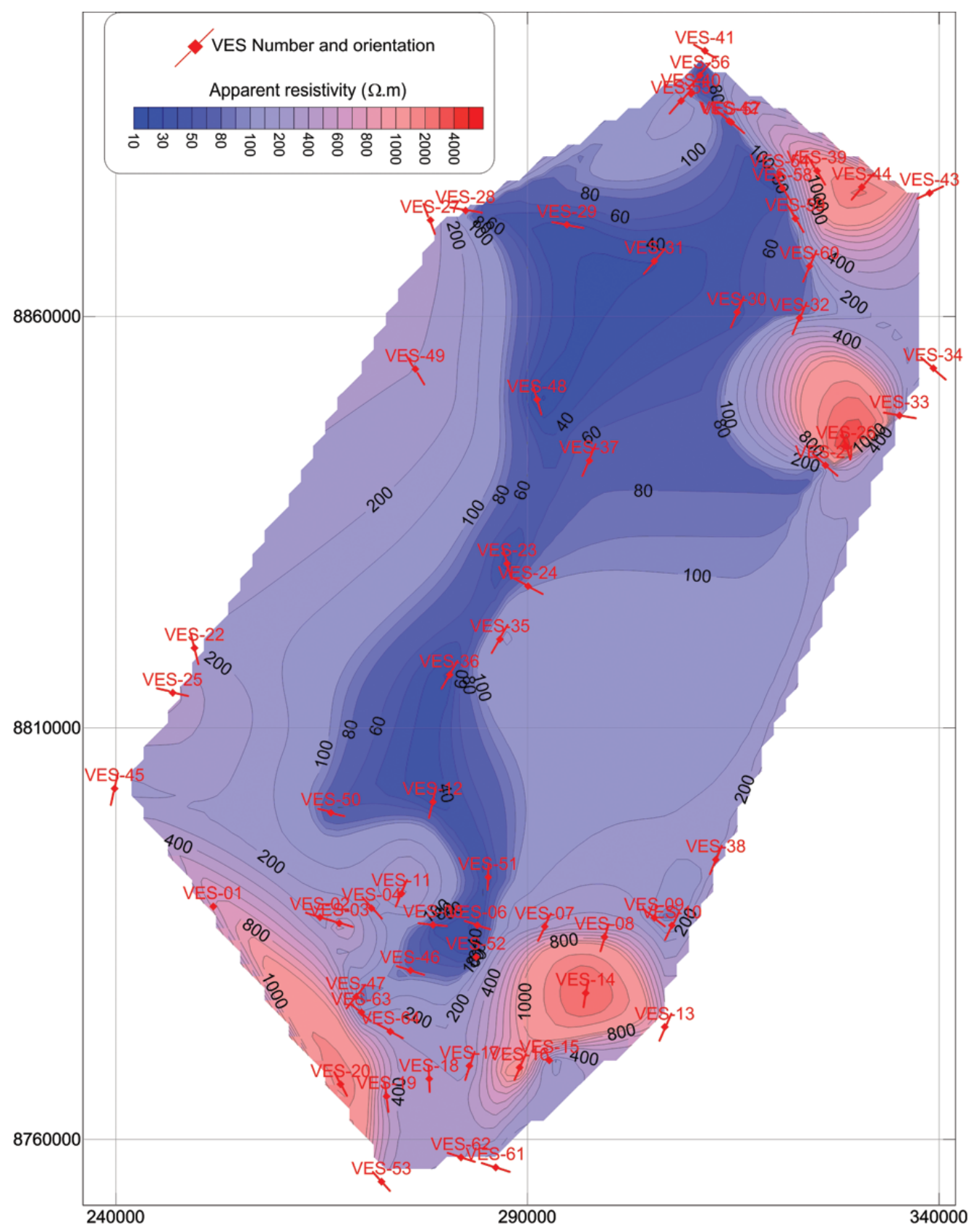

Figure 2 - Apparent resistivity map of the Salitre basin for AB/2 spacing of $100 \mathrm{~m}$.

rated in many places by a more or less impervious horizon or lens-shaped body. The upper zone is shallow and has a thickness smaller than $20 \mathrm{~m}$. It corresponds to the water-table aquifer developed at the top of the limestone sequence. Its resistivity value depends on the stage of karst development. The second aquifer zone has a large thickness and seems to behave as a semi-confined fractured component as it is developed below low-permeability layers. The aquifer substrate can be composed of either carbonate or highly silicified meta-sandstone.

The third pattern (Fig. 7) is a variant of the other two, illustrating geological situations in which there is only an incipient karst development, the water-table is deeper, or there is a thick impervious zone separating the karst from the fractured aquifer components. Again, the presence of such a low-permeability layer allows the assignment of a semi-confining condition to the fractured aquifer component. 


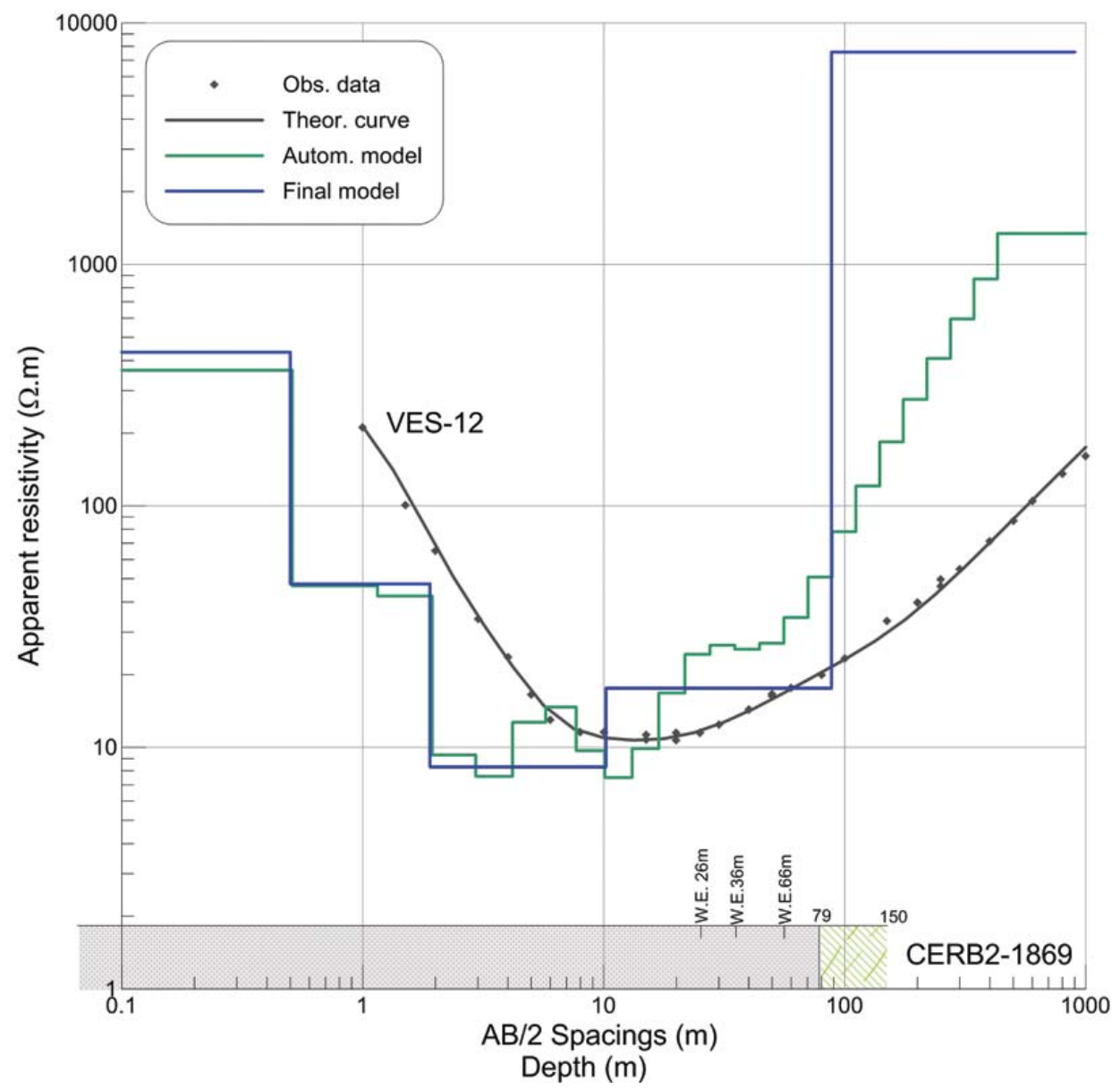

Figure 3 - Electrical sounding inversion and use of "a priori" well data for sounding VES-12.

Therefore, data from individual electrical soundings allow the possibility of distinguishing two aquifer behaviors below the region of occurrence of carbonate rocks: (i) a superior, phreatic and electrically conductive layer associated with the most karstmodified portion of the carbonate sequence; and (ii) a lower, semi-confined, thicker and more resistive layer composed of fractured limestone or meta-sandsone above an infinitely resistive impervious substrate.

In Figure 8 VES curves are shown for which the sounding centers were located in areas of the Morro do Chapéu Formation. Their inverted models reveal the existence of two or three zones of dense fracturing located at different depths in the metasandstones. The electrical-resistivity values of these intervals are relatively higher than those of the equivalent limestone, testifying to its small effective porosity, a better chemical quality of the water within these fractured zones, or both.

Geological cross sections were constructed from the interpreted geoelectrical data to highlight the structural behavior of the aquifer components identified in the area. Figure 9 shows two cross sections oriented from west to east, one in the south and another in the northern part of the synform filled with carbonate rocks. The combined thickness for the two aquifer components varies from zero, the value near the contact with the metasandstones, to as much as $250 \mathrm{~m}$ in the center of the basin. The water-table relief follows the topographic surface over the entire extent of these sections and ranges from approximately $20 \mathrm{~m}$ in the elevated parts to approximately $5 \mathrm{~m}$ in the vicinity of the valleys. The spatial aquifer-resistivity variations along the two cross sections are mainly caused by changes in the fracture density and/or in the dimensions of the dissolution channels.

A map of the distribution of the total thickness of the Salitre aquifer system, or equivalently the depth to the top of the infinitely resistive substrate, is shown in Figure 10. This semiinfinite substrate is interpreted to represent the meta-sandstone sequence with fractures closed by both depth of burial and an extensive process of hydrothermal silicification. 


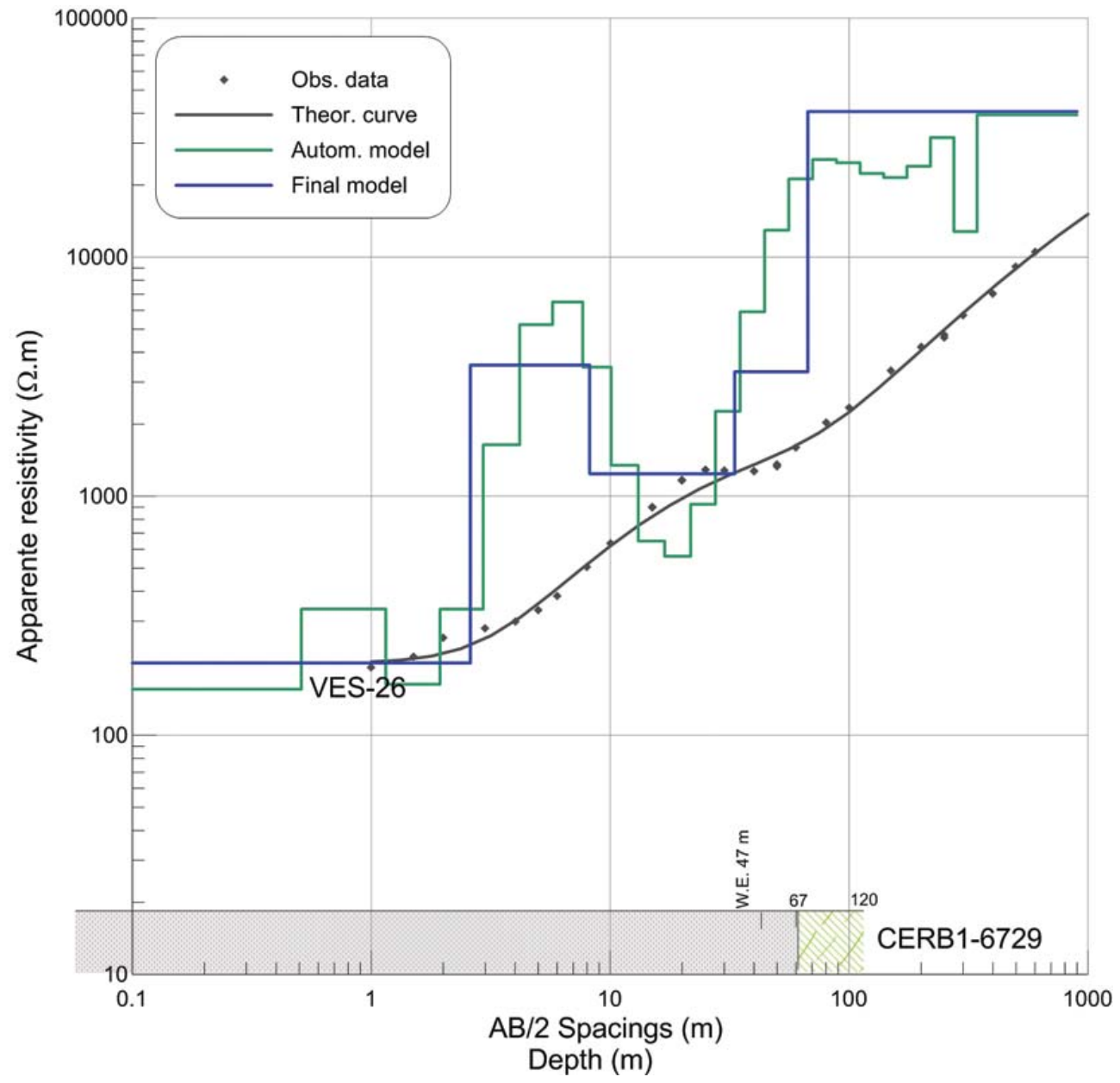

Figure 4 - Electrical sounding inversion and use of "a priori" well data for sounding VES-26.

There are three main areas where the top of the highresistivity substrate occurs at greater depths, which may be suggested as the most favorable locations for high-production wells: Area I, in the northern basin lobe, related to the structural lineaments that control the courses of the Pacuí river and the Piabas creek; Area II, just below the first, centered around the Salitre River itself; and Area III, in the southern basin lobe, related to the structures that underlie the Salitre River and its tributaries. Near to these zones are observed areas of closed electrical contours, where the substrate is close to the surface. These topographic irregularities may existed prior to the basin fill or were tectonically developed after the deposition of the carbonate sequence.

\section{GEOELECTRIC TOMOGRAPHIC DATA}

To test a geoelectric acquisition scheme for a more efficient way to locate production wells in the area of the Salitre Formation, five geoelectrical tomographic cross sections were performed, both parallel to and across the main drainage currents of the area (see Fig. 1 for locations). The sections were defined and oriented as follows: (i) Two were defined to study the Pacuí river valley near Casa Velha village and close to the Sumidouro bridges. For the first (transverse 1), parallel to and almost inside the valley (WSW-ENE), five sounding measurements numbered as S-1 to S-5 were collected with centers spaced approximately $1 \mathrm{~km}$ apart. The second (transverse 2) crossed the valley and had six sounding measurements with equidistant centers sepated by approximately $1 \mathrm{~km}$ spread along the road from Casa Velha to Alazão; (ii) The third (transverse 3 ) was oriented transversely to the course of the Piabas creek, along the road from Curralinho to Alazão, in the NE sector of the area. It contained 11 sounding centers, numbered from S-5 to S-1 and S-2 to S-10, with distances ranging from 1000 to $1500 \mathrm{~m}$, (iii) The fourth and fifth (transverses 4 and 5) were located in the upper zone of the basin. One, with five soundings lay along the road through the village of Tábua and 


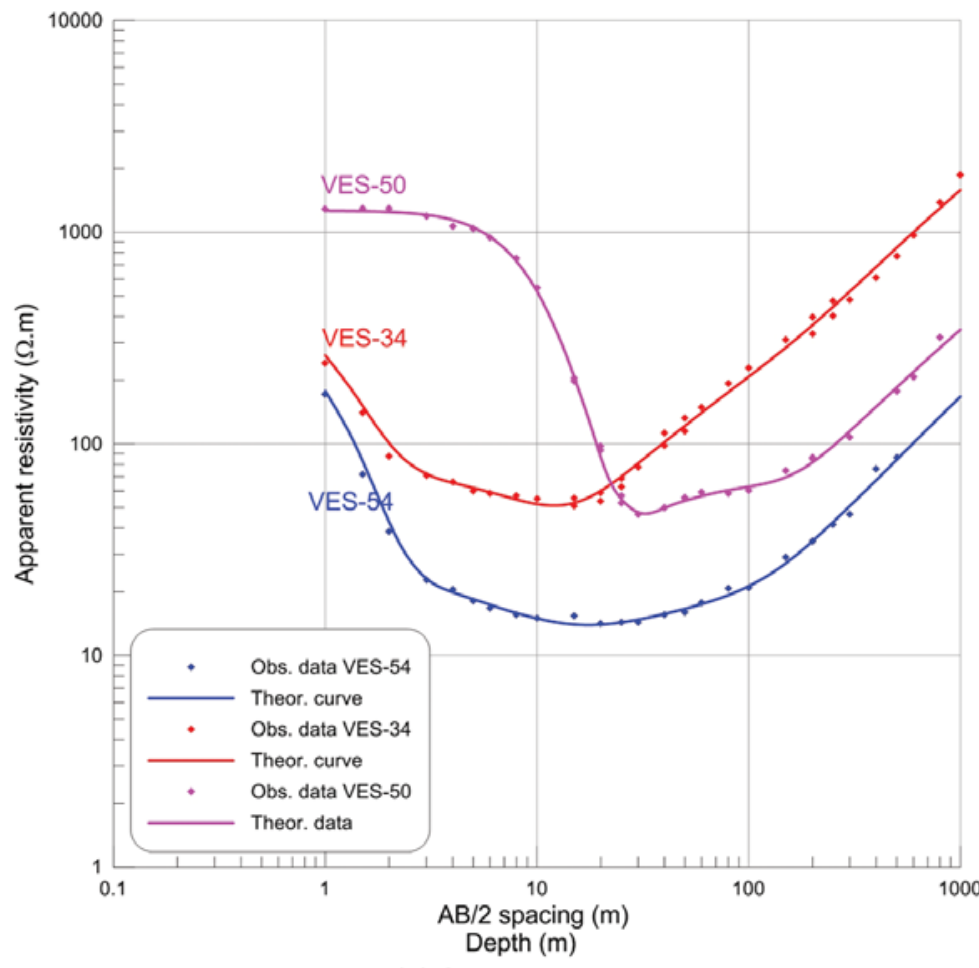

(a) Sounding curves

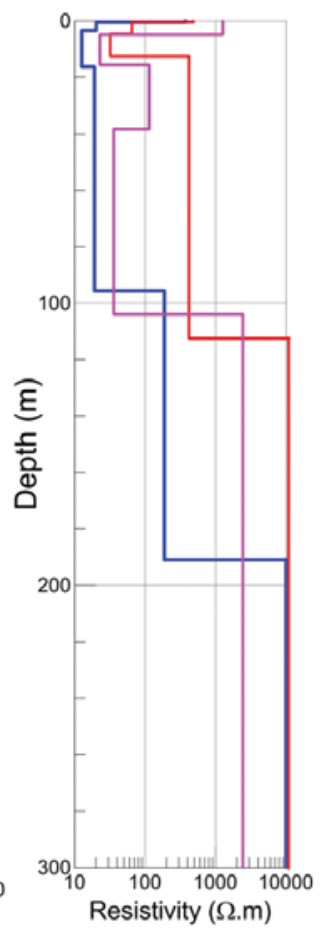

(b) Final models

Figure 5 - Electrical sounding inversion for sounding of type 1.

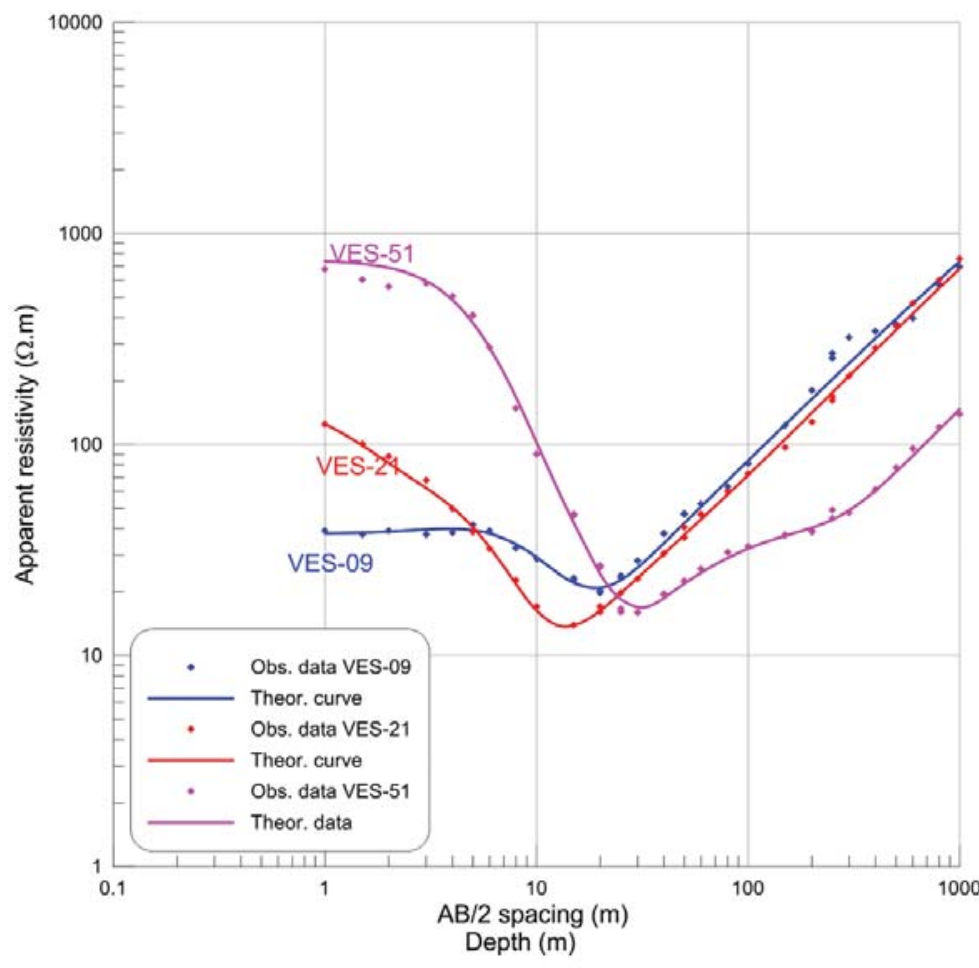

(a) Sounding curves

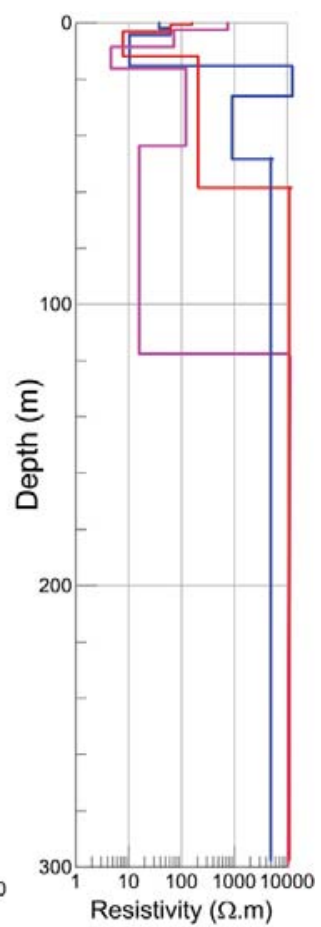

(b) Final models

Figure 6 - Electrical sounding inversion for sounding of type 2. 


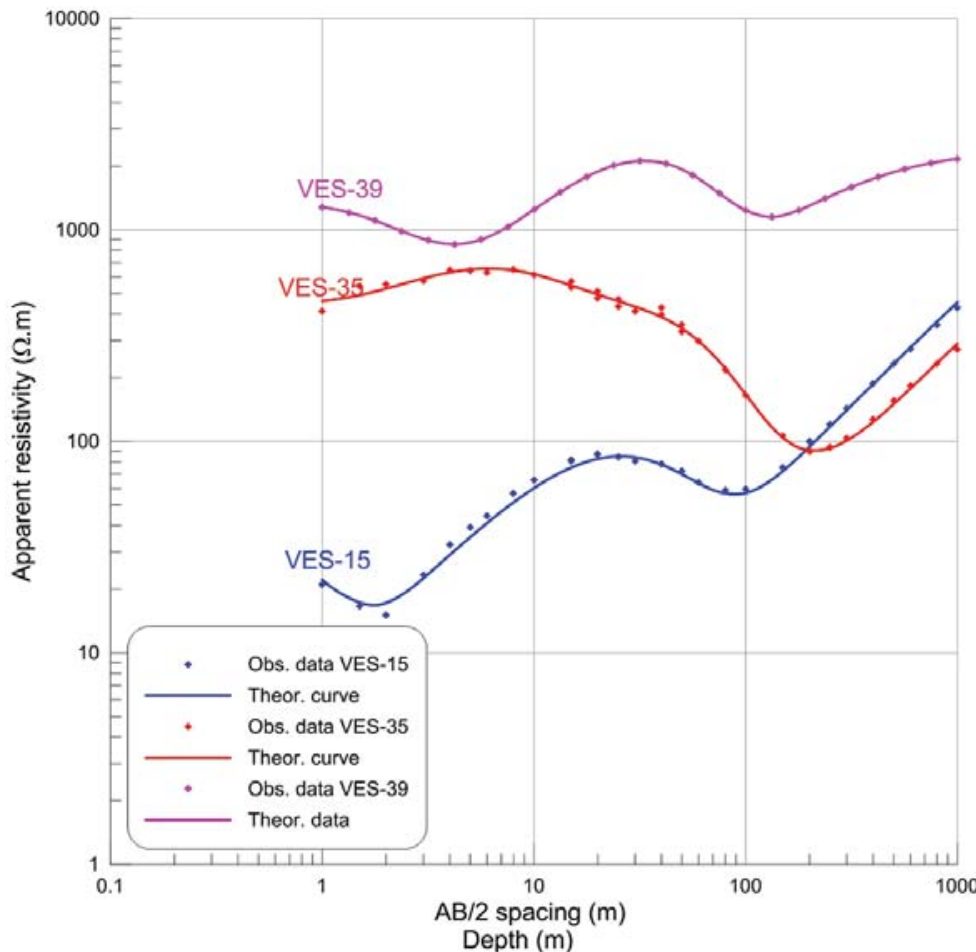

(a) Sounding curves

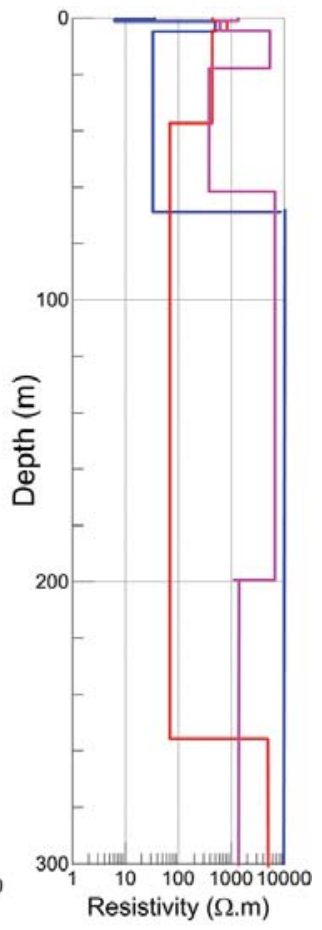

(b) Final models

Figure 7 - Electrical sounding inversion for sounding of type 3.

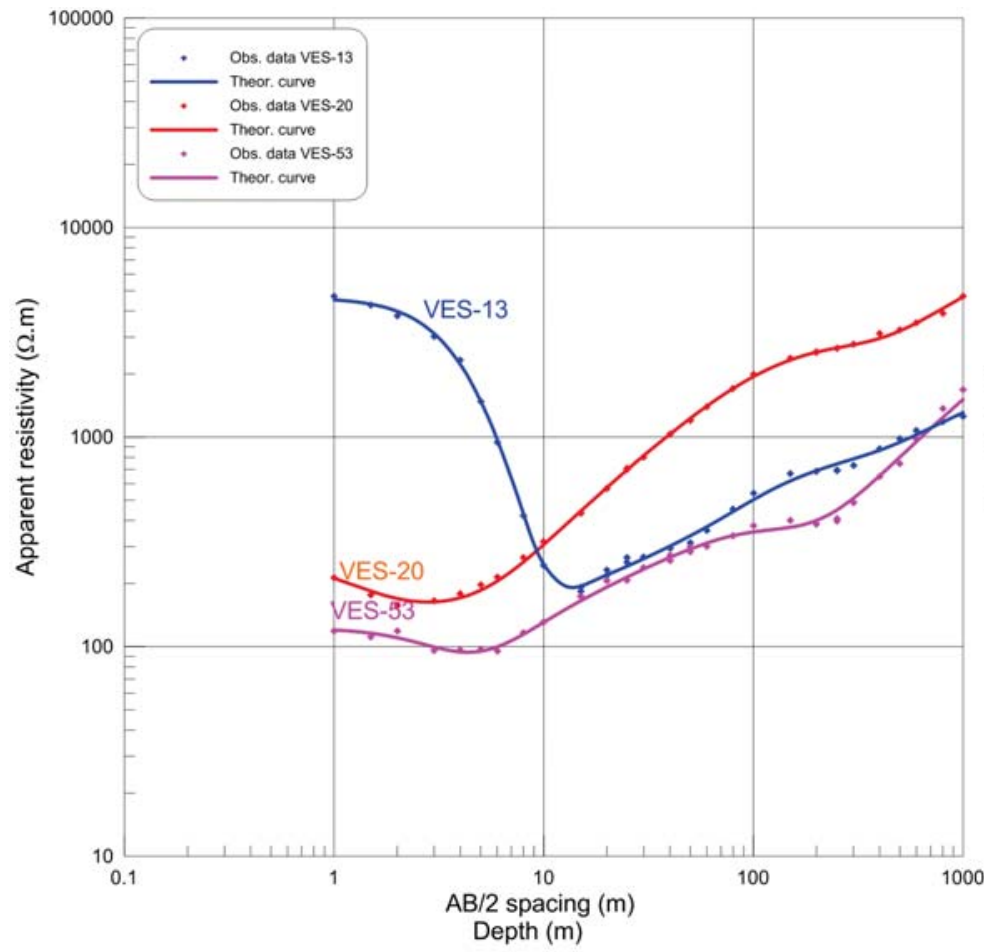

(a) Sounding curves

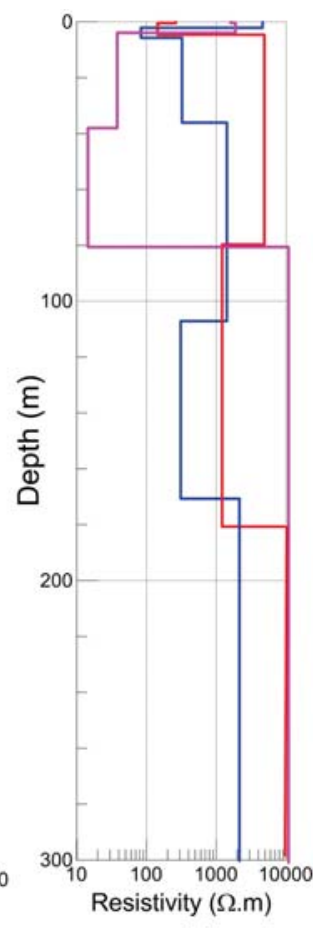

(b) Final models

Figure 8 - Electrical sounding inversion for sounding centered outside the Salitre carbonates. 

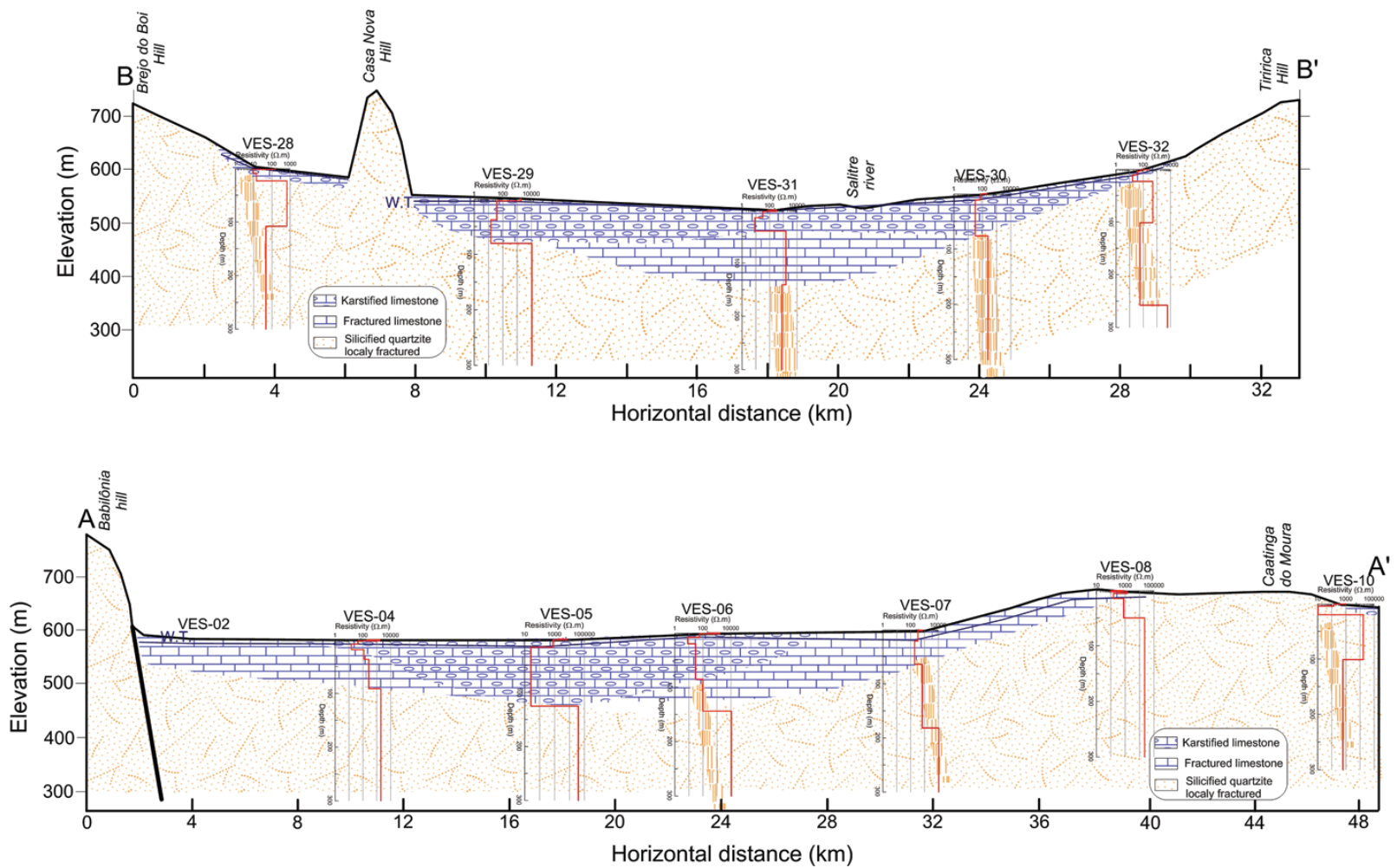

Figure $\mathbf{9}$ - Typical geological cross sections through the Salitre river basin.

was oriented NNW-SSE, ending near the well CERB1-7827, which was drilled to supply the local population of the village. This flowing well has a depth of only $30 \mathrm{~m}$ and a natural discharge of $13 \mathrm{~m}^{3} / \mathrm{h}$. The other profile, not included in the paper, was oriented from SE to NW and had six centers located along the road from Várzea Nova to Molungú, starting at $1 \mathrm{~km}$ from the Várzea Nova exit.

Figures 11 illustrates the observed and calculated apparentresistivity sections and the inverted geoelectrical models (shown at the bottom) for tomographic transverse 1, parallel to the Pacuí river, in the northern part of the area. The observed $\rho_{a}$ contours (Fig. 11a) have high values ( $>250 \Omega . \mathrm{m}$ ) on the SW side and below an $A B / 2$ value of $200 \mathrm{~m}$; lower values $(<80 \Omega$.m) prevail below the centers of S-3, S-4 and S-5, which are associated with local fracture zones transverse to the cross section. The inverted section highlights the existence of an extensive, well-defined resistive zone occurring below S-6 and S-2, which is bounded by a thick subvertical conductive zone (S-3) that extend below the maximum depth investigated by the soundings. The fracture zone under S-3 seems to have a large karst development, judging from its low resistivity value. The inverted results show that in the region between S-3 and S-5, there is an essentially horizontal earth structure with an upper karst layer of up to approximately $80 \mathrm{~m}$ in depth and a lower horizon that behaves as a thick fractured package (carbonate or meta-sandstone). Plotted over the inverted geological section are the one-dimensional models obtained for soundings S-2 and S-4 to demonstrate the validity of the hypothesis used to justify the use of the electrical sounding technique for these regional aquifer investigations.

Figure 12 shows the results for tomographic transverse 2 normal to the Pacuí river course. The data and the inverted model both reveal the presence of an wide, good conductive karstified zone (>500 $\mathrm{m}$ thickness) related to deep fracturing along the river valley, delimited by zones of high-resistivity materials. The thickness of the karst-carbonate layer is thin outside the river plain, what makes difficult to distinguish non-fractured limestone from the quartzite substratum.

Figure 13 contains the data and the results obtained for the geoelectric transverse 3, crossing the Piabas creek. Once again the data indicate the existence of areas of great karst development at the ends of the sections, enclosed or superposed by more resistive horizons. In the central region, the $\rho_{a}$ values are higher than those of the previous sections that are shown in Figures 11 and 12. The inverted geoelectric model reflects a geological 


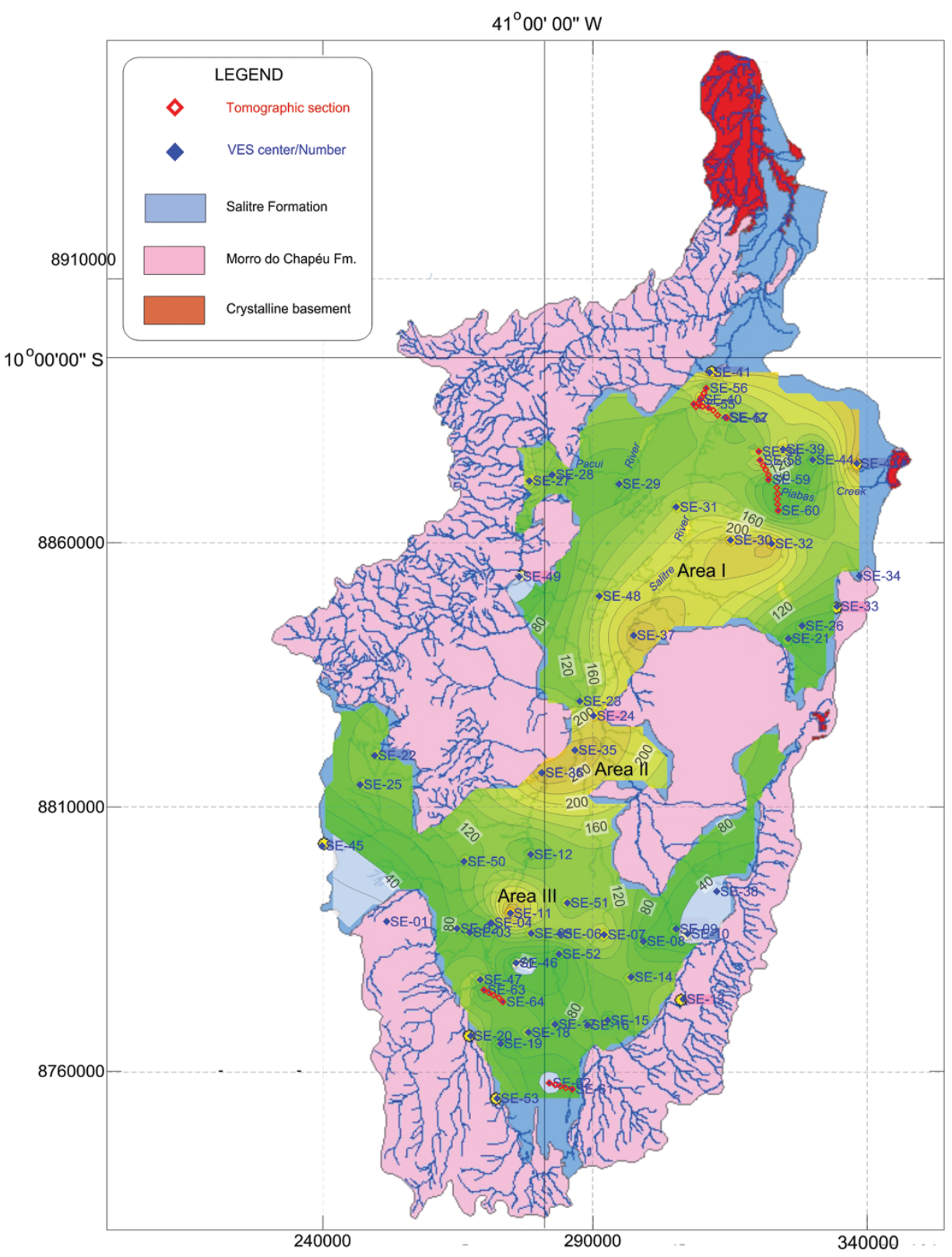

Figure 10 - Map of the total aquifer thickness within the Salitre river basin.

structure defined by horizontal and vertical interfaces with large resistivity contrasts. The vertical interfaces delimit areas of contrasting fracture densities. The horizontal interfaces represent the vadose zone, fractured zones with intense karst dissolution, fractured zones free of dissolution and the less-fractured closed substrate. The central block of higher resistivity (>600 $\Omega$.m) between S-1 and S-9 suggests the presence of a meta-sandstone substrate very close to the surface.

The results for transverse 4, obtained near the village of Tábua, are shown in Figure 13. In general, the observed $\rho_{a}$ val- ues are much higher than those of the previous sections, suggesting the absence of any karst dissolution. The inverted geoelectrical model allows the interpretation of the high-resistivity substrate as consisting of impervious rocks along the length of the profile. Although this part of the basin is included within the carbonate coverage (Fig. 1), well CERB1-3915 located near S-1 reveals the presence of fractured meta-sandstones up to a depth of $30 \mathrm{~m}$. The one-dimensional inversion model of sounding S-4, plotted on the inverted model (Fig. 13c) again serves to support the approximate validity of VES to study the Salitre aquifer system. 

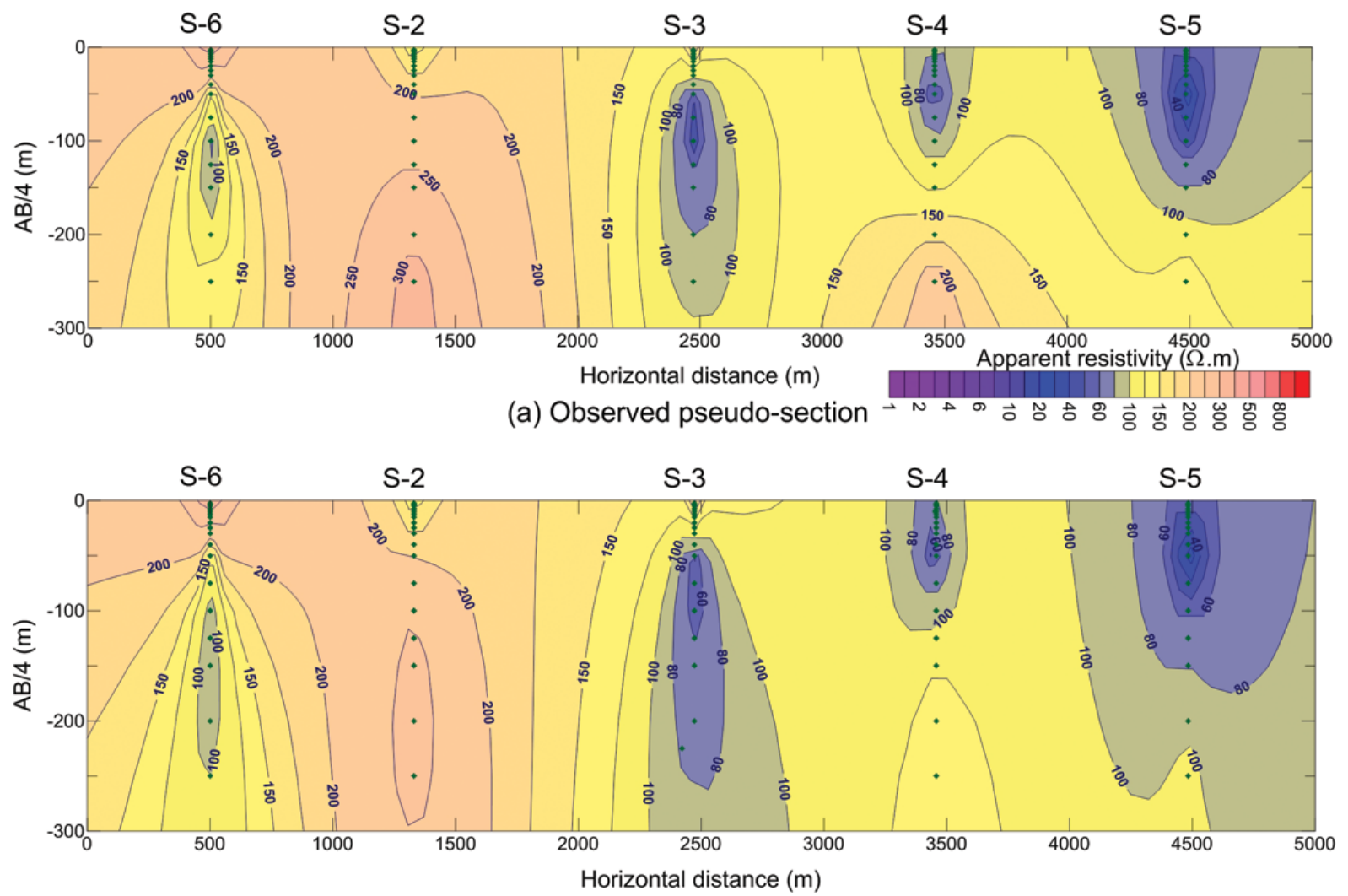

(b) Computed pseudo-section

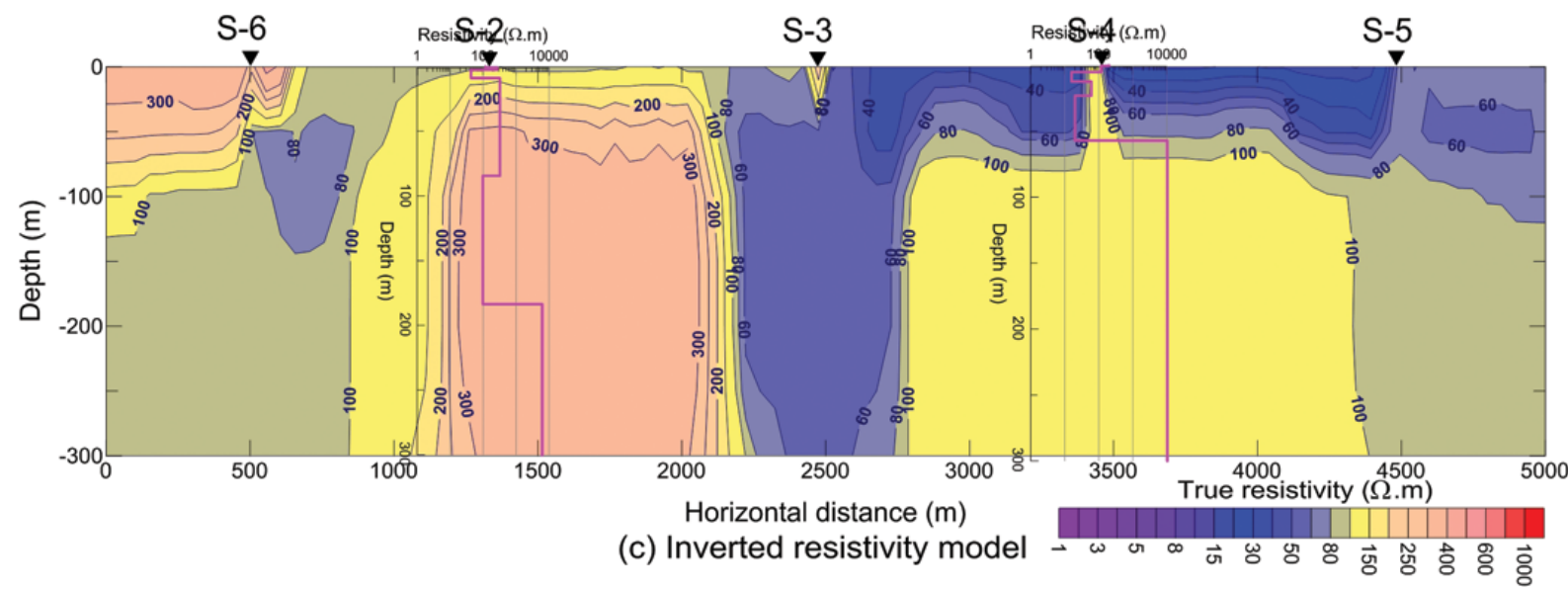

Figure 11 - Subsurface resistivity distribution along transverse 1 and interpreted geoelectrical models.

\section{DISCUSSION AND CONCLUSIONS}

The geological and geophysical information obtained in this study suggest that there is a large amount of stored groundwater that, if exploited efficiently and in a conservative way, will be more than sufficient to meet the current and future demands of the urban, agricultural and industrial activities in development in the region. The collected data have also allowed the regional aquifer to be subdivided into two main components: a water-table component, of moderate thickness but high storage capacity and productivity, that produces slightly saline water in the basin; and a semi-confined component of a larger thickness, storage capacity and intermediate productivity that produces fresh potable water. The efficient exploitation of this aquifer system will require the construction and completion of production wells that balance the main characteristics of these two components. 

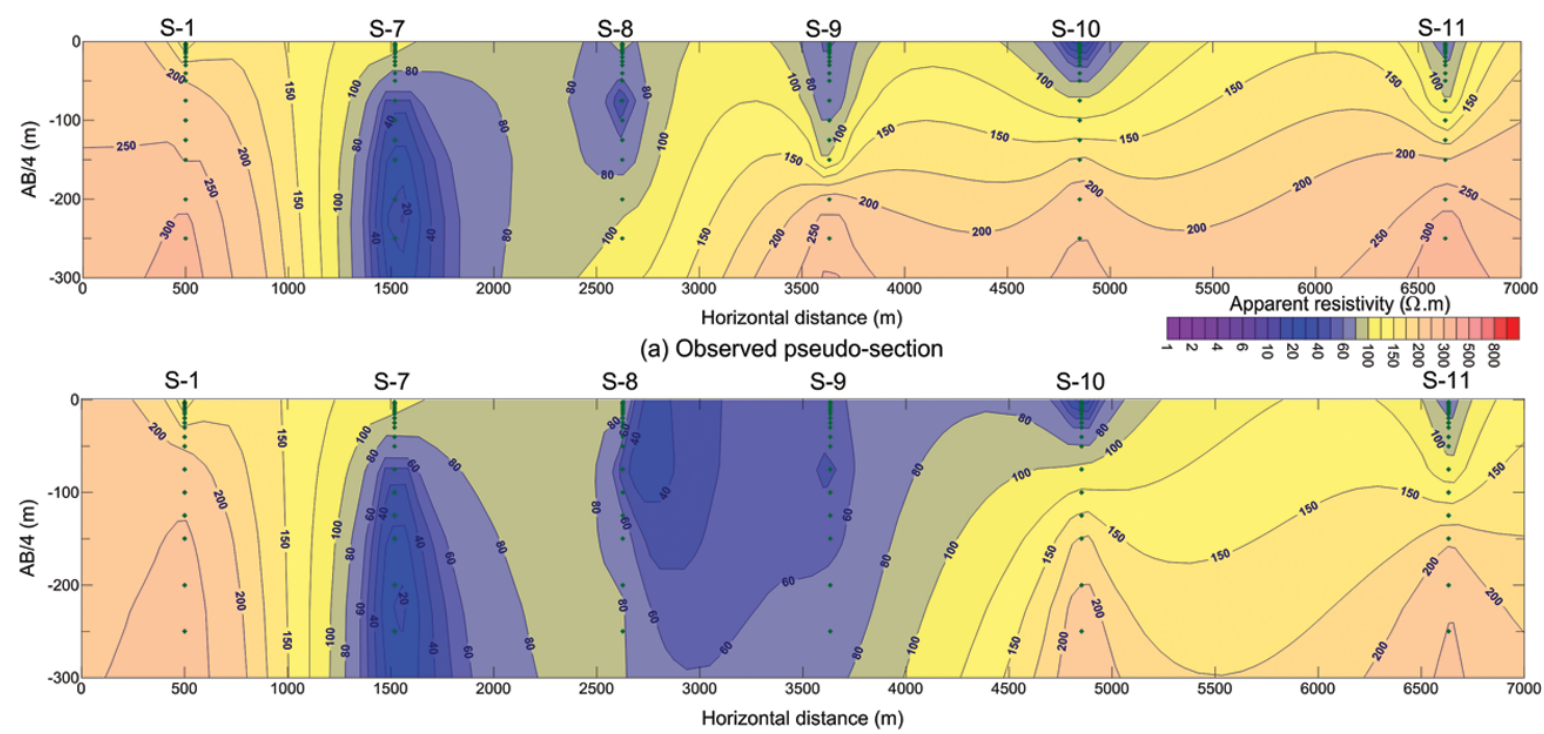

(b) Computed pseudo-section

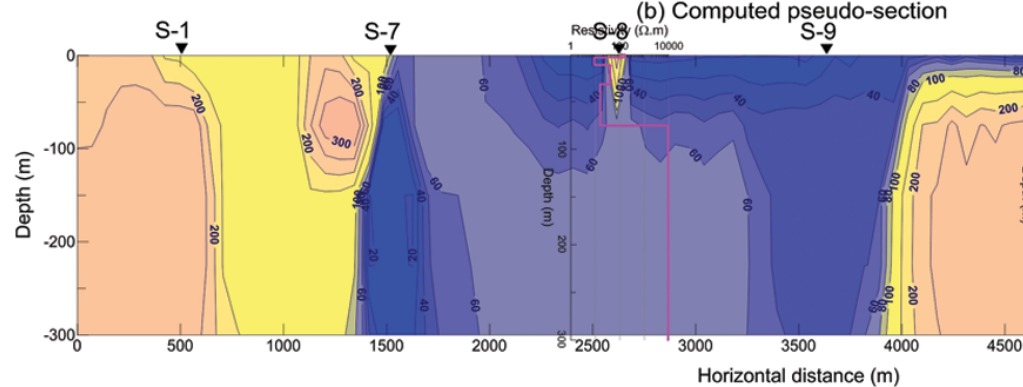

(c) Inverted resistivity mode

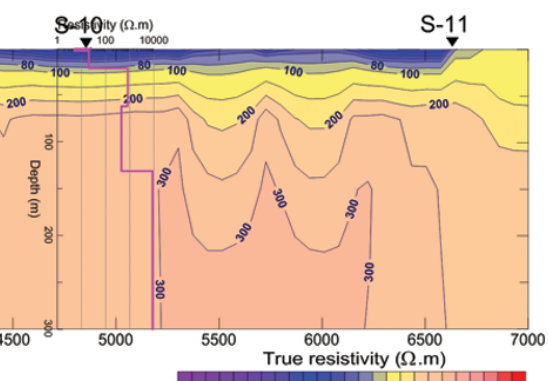

W ज

Figure 12 - Subsurface resistivity distribution along transverse 2 and interpreted geoelectrical models.

The data from electrical soundings and tomographic sections suggest the following patterns of variation in the true resistivity of the formations: (i) for the karst/water-table component, the range of resistivity varies from 30 to $100 \Omega . \mathrm{m}$; and (ii) for the semi-confined component (fractured limestone and/or meta-sandstone), the resistivity varies from 100 to $600 \Omega$.m. Values above $600 \Omega . m$ should be considered to indicate a low-productivity aquifer, while values above $2000 \Omega$.m indicate aquitards.

Measurements of the electrical resistivity of the water that was taken from samples of wells in the basin suggest a pattern of progressive decrease from south to north, reflecting a general increase in salinity along the hydraulic-flow path. With the data available, it is possible to identify the following regionalization: (i) in the headwater zone of the Salitre River, up to the city of Ourolândia, the resistivity is high, ranging from 25 to $50 \Omega$.m; (ii) in the intermediate zone of the basin, the resistivity values fall in the range of 12.5 to $25 \Omega . \mathrm{m}$; and (iii) in the low Salitre course, the resistivity reaches values in the range of 8.3 to $12.5 \Omega$.m.
Combining the above results, using Archie's law for fractured aquifers (with or without karst development), yields an average effective porosity value between 12.5 and $42 \%$ for the water-table component and between 5 and $15 \%$ for the semi-confined component. Taking $15 \%$ as a representative porosity value and an average thickness of $150 \mathrm{~m}$ for the whole aquifer system, a stored groundwater reserve of 100 billion cubic meters in the Salitre aquifer system can be estimated.

The carbonate rocks of the Salitre Formation contain the water-table component of the aquifer system in the region. Because of its adequate thickness and high effective porosity developed by dissolution, it stocks a large groundwater reserve. In many places, because of these conditions, wells drilled into this component have high flow rates. In particular, high-production wells (over $30 \mathrm{~m}^{3} / \mathrm{h}$ ) have been located in the high Salitre area, from Varzea Nova to São Tomé village. However, the produced water usually has a high salinity and hardness and is not recommended for human consumption. In the fractured semiconfined component, which may be combining the influence of 


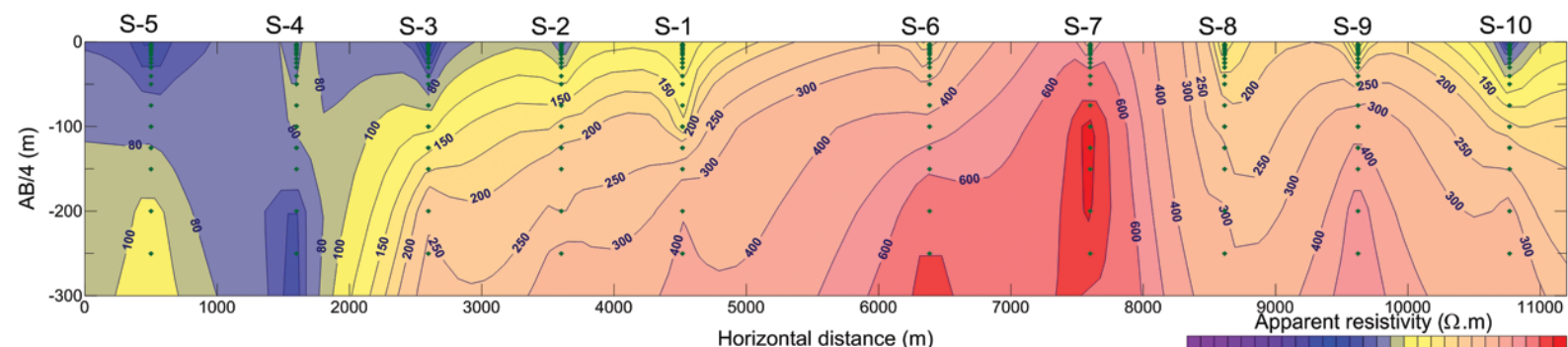

(a) Observed pseudo-section
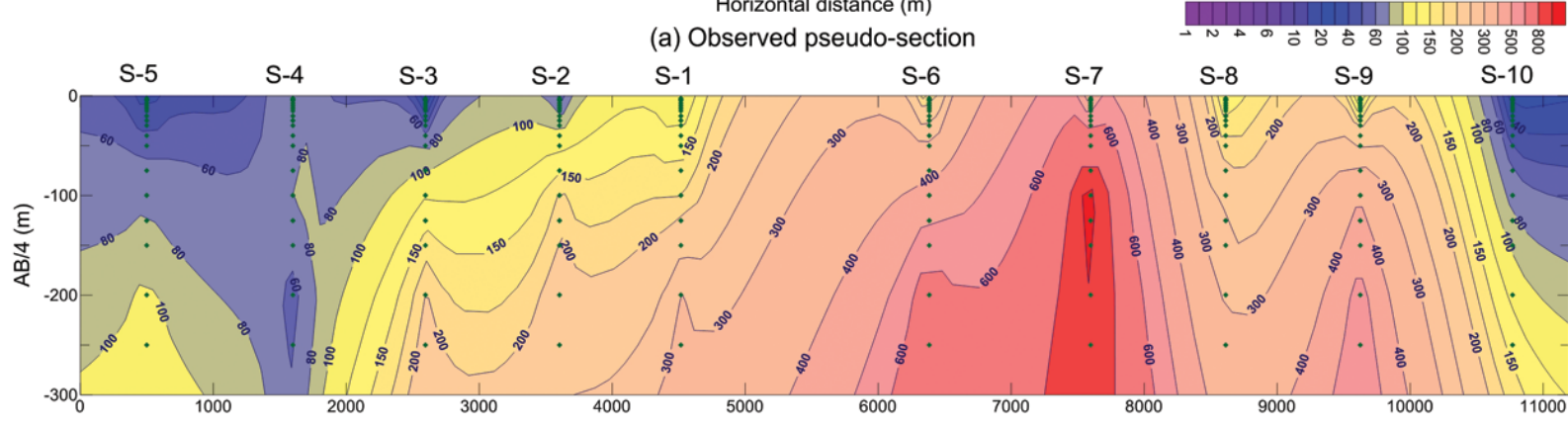

Horizontal distance $(\mathrm{m})$

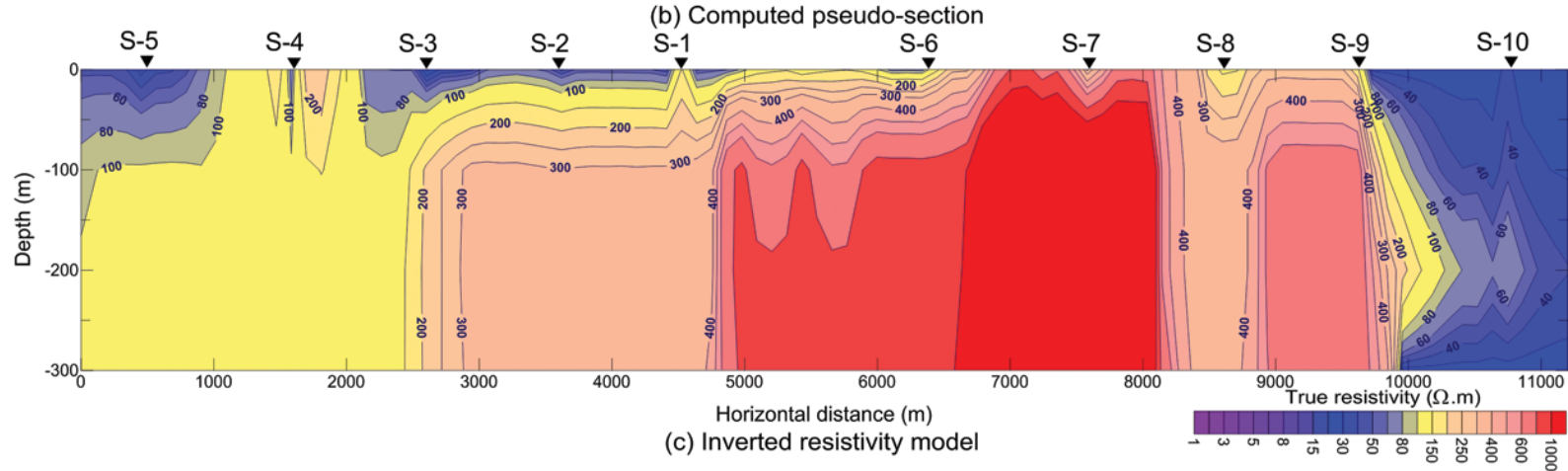

Figure 13 - Subsurface resistivity distribution along transverse 3 and interpreted geoelectrical models.

the carbonates of the Salitre Formation with that of the metasandstones of the Morro do Chapéu Formation, the average productivity of the wells is good, and the waters have low salinity, which is well suited to human consumption.

The geophysical results suggest that geoelectric tomography is an efficient technique for selecting favorable places to locate water production wells in the basin, and this technique may also assist in the constructive design and completion of such wells for the optimum exploitation of the available groundwater.

\section{ACKNOWLEDGEMENTS}

The author thank the Brazilian National Council for Scientific and Technological Development (CNPq) for the financial support of the Hidrosalitre Project (Proc. No. 475655-03-6) and for granting his research productivity fellowship. He also extends thanks to CPGG/UFBA for the environment and the support for the development of the research project and to the project's research team, A.E.G. Azevedo, J.A.G. Luz and L.R.B. Leal, for discussions and exchanges of experience during the execution of the research. Finally, the author would like to thank to the M.C. in Geology A.G. Mendes and to the technicians L.M. Santos and J.M. Paz for their effective participation in the geophysical field work.

\section{REFERENCES}

AULER AS \& SMART PL. 2002. Toca da Boa Vista (Campo Formoso), BA - A maior caverna do Hemisfério Sul. In: SCHOBBENHAUS C, CAMPOS DA, QUEIROZ ET, WINGE M \& BERBERT-BORN M (Eds.). Sítios Geológicos e Paleontológicos do Brasil. Brasília, Brazil. DNPM/ CPRM - Comissão Brasileira de Sítios Geológicos e Paleontológicos (SIGEP), v. 1, 443-452.

BRIT0 LTL. 2003. Avaliação de impactos das atividades antrópicas sobre os recursos hídricos da bacia hidrográfica do rio Salitre-Bahia e classificação das fontes hídricas. Doctorate thesis, Universidade Federal de Campina Grande, Campina Grande, Brazil, 186 pp. 


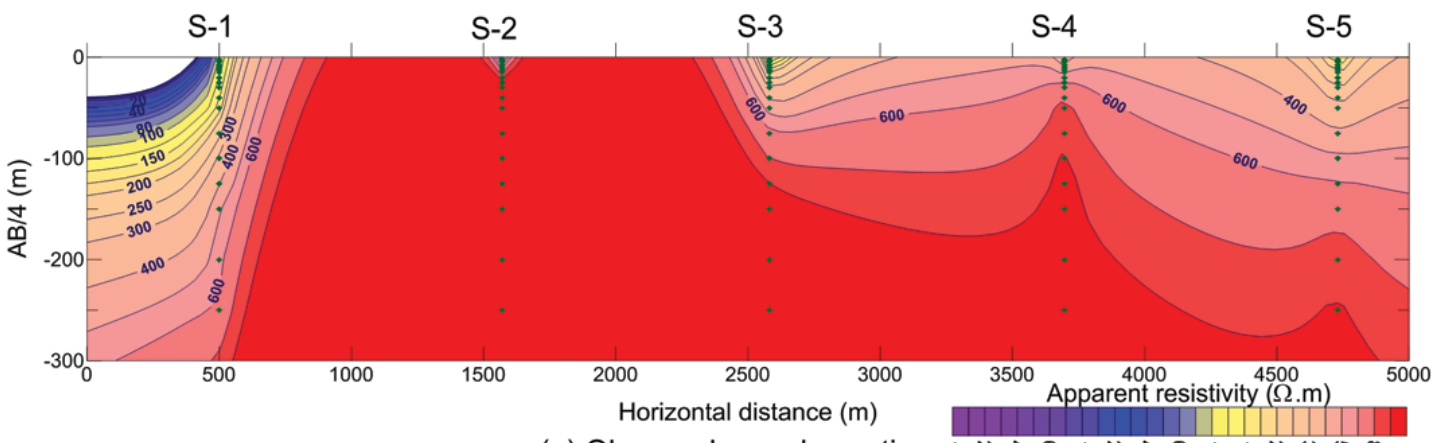

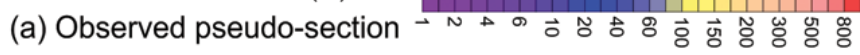

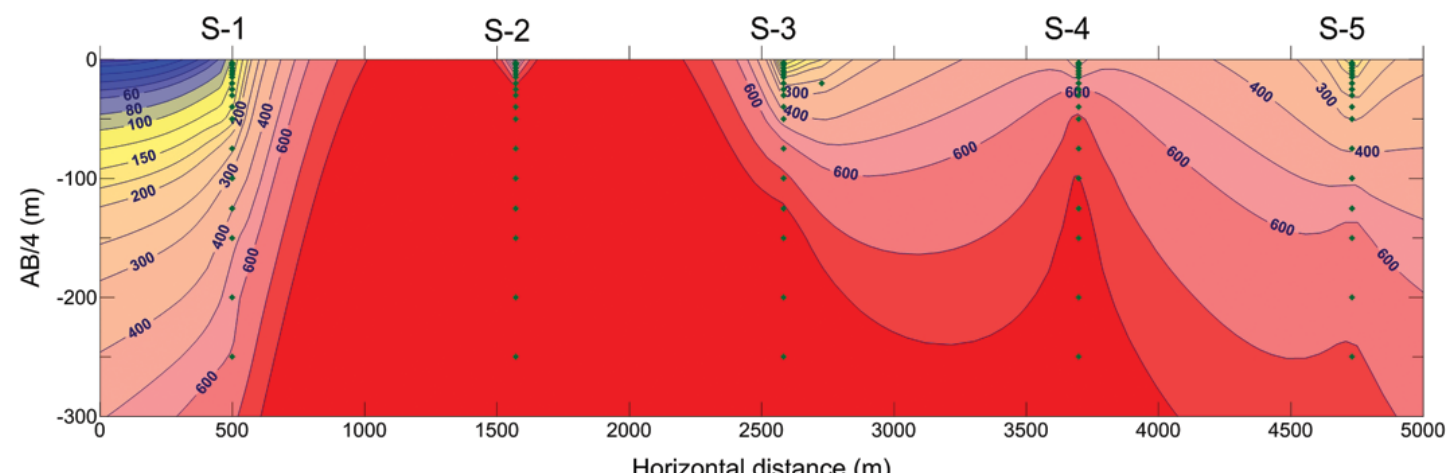

(b) Computed pseudo-section

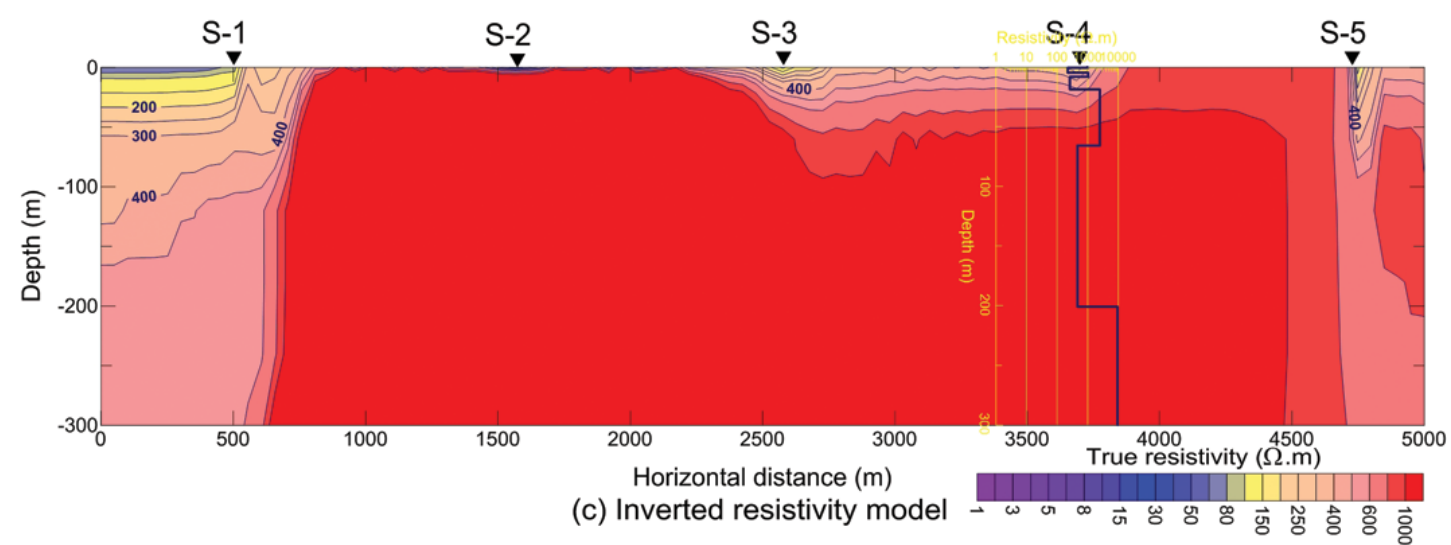

Figure 14 - Subsurface resistivity distribution along transverse 4 and interpreted geoelectrical models.

CBPM - Companhia Baiana de Pesquisa Mineral. 2004. Estudo e definição do modelo hidrogeológico da bacia do rio Salitre, onde ocorrem os depósitos do "Mármore Beje-Bahia". CBPM, Salvador, Brazil, $63 \mathrm{pp}$.

CEI - Centro de Estatística e Informações. 1986. Avaliação dos recursos hídricos das bacias hidrográficas do estado da Bahia - bacia do rio Salitre. Secretaria do Planejamento, Ciência e Tecnologia, Salvador, Brazil, $101 \mathrm{pp}$.

GUIMARÃES JT, ALKMIM FF \& CRUZ SCP. 2012. Supergrupos Espinhaço e São Francisco. In: BARBOSA JSF (Coord. Geral). Geologia da Bahia - Pesquisa e Atualização. Companhia Baiana de Pesquisa Mineral (CBPM), Salvador, Bahia, Brazil, v. 2, 33-85.

KOEFOED 0. 1979. Resistivity Sounding Measurements: Geosounding Principles. Methods in Geochemistry and Geophysics. Elsevier. Amsterdam. 276 pp.

LIMA OAL. 2003. Geossistemas e recursos hídricos: água subterrânea no Estado da Bahia. Revista Bahia Análise \& Dados, 13: 391-402.

LIMA OAL \& SRI NIWAS. 2000. Estimation of hydraulic parameters of shaly sandstones from geoelectrical measurements. Journal of Hy- 
drology, 235: 12-26.

VANDER VELPEN BPA \& SPORRY RJ. 1993. RESIST. A computer program to process resistivity sounding data on $\mathrm{PC}$ compatibles. Computer \& Geosciences, 19(5): 691-703.

VOZOFF K. 1958. Numerical resistivity analysis: Horizontal Layers. Geophysics, 23: 536-556.

WARD SH. 1990. Resistivity and induced polarization methods. In:
WARD SH (Ed.). Geotechnical and Environmental Geophysics, Volume I: Review and Tutorial. Investigations in Geophysics no. 5. Society of Exploration Geophysicists. Tulsa, OK. 147-189.

WIKIPEDIA. 2009. Toca da Boa Vista. Available on: < http://pt.wikipedia. org/wiki/Toca_da_Boa_Vista >. Access on: September 20, 2009.

ZOHDY AAR. 1989. A new method for the automatic interpretation of Schlumberger and Wenner sounding curves. Geophysics, 54: 245-253.

Recebido em 26 julho, 2013 / Aceito em 8 setembro, 2014

Received on July 26, 2013 / Accepted on September 8, 2014

\section{NOTE ABOUT THE AUTHOR}

Olivar Antônio Lima de Lima. Bachelor in Geology (1967) and Master of Science in Structural Geology (1970) from the Universidade Federal do Rio de Janeiro (UFRJ). Doctor in Geophysics (1979) from the Universidade Federal da Bahia (UFBA). Postdoctoral Fellow (1989-1990) at the Department of Petroleum Engineering, University of Texas, Austin. Full Professor of the Geosciences Institute, UFBA. Main research interests: electric and electromagnetic methods applied to petroleum and groundwater exploration and to geotechnical and environmental problems. Active member of SBGf, SEG and EAGE. 